\title{
INTEREST AND MOTIVATION ANALYSIS OF LECTURER IN STATE POLYTECHNIC OF BALIKPAPAN TO LEARN ENGLISH (QUALITATIVE-QUANTITATIVE RESEARCH)
}

\author{
Lilik Damayanti $^{1^{*}}$ and Elisabeth Milaningrum ${ }^{2}$ \\ ${ }^{I}$ Dept of Civil Engineering, State Polytechnic of Balikpapan \\ ${ }^{2}$ Dept of Mechanical Engineering, State Polytechnic of Balikpapan \\ "e-mail: lilik.damayanti@poltekba.ac.id
}

\begin{abstract}
The purpose of this study are (1) to determine the interest and motivation of lecturer in State Polytechnic of Balikpapan to English; (2) to determine the relationship between interest and motivation toward their result in English learning activity. There are two data that used in this research, the first data is taken from the result of English learning activity, and the second data is taken from questionnaires which given to the 20 respondent. Distribution of questionnaires is given to the lecturer in State Polytechnic of Balikpapan. The questionnaires consist of several questions that can determine the interest and motivation to learn or involve in English learning activity. And the data from English learning activities is used to analyze whether there is any relationship between them. The analysis of data is given through the descriptive method. The results showed that (1) There is an interest of the lecturer in State Polytechnic of Balikpapan to follow the English training, it shows with the frequency of "always" in 94 frequency as the biggest one than other, but also there are a few of them has no interest to follow that training. (2) There is a motivation of the lecturer in State Polytechnic of Balikpapan to learn English but they have difficulties to understand the materials. (3) There is a well-motivated with Lowachievement Category for the lecturer of State Polytechnic of Balikpapan, means that their lower comprehend ability and score are not caused of their lower interest, but it caused of their former skill is not good enough.
\end{abstract}

Keywords: interest, motivation, Learning achievement, English learning

\section{Introduction}

Globalization in all sectors insist the increasing of Human resources include the lecturer, as the main individual in high education and also the staff that become the supporting unit to achieve institution goals. The output of high education is needed to be qualified in making of high competency and good quality ${ }^{[1]}$. One of effort is increasing the quality of English. English mastering will open a new gate for them toward the development of science and technology, include the education that can be accessed easily from many resources.

The difficulties of learning English is still happen to the lecturer in high education. From many activities that has been done shows that their interest and motivation are still low toward the activity that is related to English learning.
The successful of someone in achieving English is not only determined by the quality of that person, but it is also determine by the existing of the institution, learning motivation and process ${ }^{[2]}$. The conducive situation of institution depends on: aims and mission of institution; management; attitude between staff; lecturer role; monitoring system; supporting facility; Institution effort to make changes; and open communication [3]. The quality of output and outcome depends on the lecturer role in doing their learning activities ${ }^{[4]}$. The active lecturer will be depends on their interest and motivation due to learning process. The higher interest and motivation in learning will support the increasing of learning result. 
The information about interest and motivation will be used for the basic in

strategy which is relevant with the lecturer and staff needs. Therefor, it needs a research of interest and motivation of English learning which involved the lecturer in State Polytechnic of Balikpapan.

The system of modern learning is ideally based on needs analysis. This Need analysis become a procedure in collecting the information about learning needs on specific learner, it is to formulate the purpose and learning material. Therefor it needs deep analysis such as the collecting of data through questionnaires, then validation with the result of activity that has been done before.

\section{Research Methodology}

There are five phases of research, the first phase is preliminary studies by identified the problems and potential that appears in State Polytechnic of Balikpapan. The second phase is the theory analysis by using literary review that related to the interest and motivation. The next phase is the collecting of data because the research in conducted in quantitative and qualitative method therefor the data is taken from questionnaires and result of activity that has been done before, the data will be analyzed and compared by using both data. The four phase is test the theory, in this phase the researcher will test the theory which taken from literary review and also the data from observation by identifying, showing and explaining the result from questionnaires, and also from English learning activity through descriptive method. And the last phase is data analysis, in this phase the researcher applied the descriptive analysis through qualitative and quantitative ${ }^{[5]}$.

There are two data that used in this research, the first data is taken from the result of English learning activity, and the determine the purpose, method, and

second data is taken from questionnaires which given to the 20 respondent. Distribution of questionnaires is given to the lecturer in State Polytechnic of Balikpapan. The questionnaires consist of several questions that can determine the interest and motivation to learn or involve in English learning activity. And the data from English learning activities is used to analyze whether there is any relationship between them. The analysis of data is given through the descriptive method.

\section{Result And Discussion}

\section{Interest}

The data of interest is taken from the questionnaires that give to the lecturer and also the data from attendance list of lecturer in State Polytechnic of Balikpapan to follow the English training that has been done before by the Language Centre. Those data are given to the twenty lecturers as respondent, which has ten questions in it. The graph of their presence in English training can be shown as follows:

Picture 1. Graph of attendance percentage in TOEFL Training

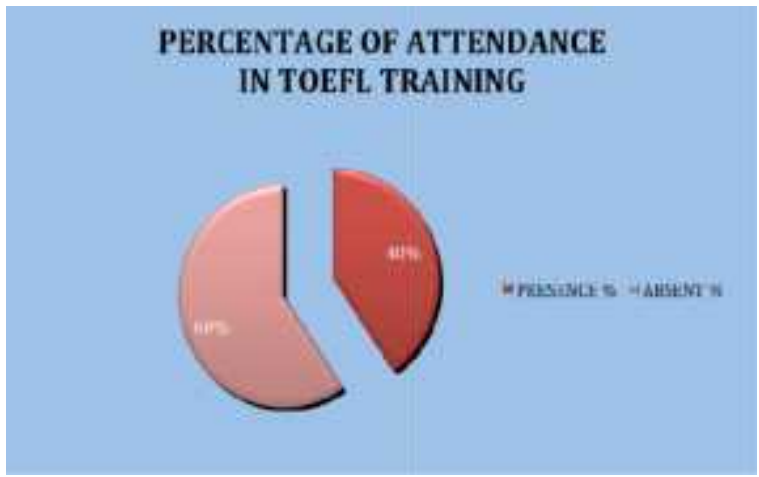

The researcher also gives the distribution from interest variable in form of interest frequency distribution table as follows: 
Table 1. Interest frequency From the table above, it can be concluded

\begin{tabular}{|c|c|}
\hline Interest & Frequency \\
\hline Always & 94 \\
\hline Sometimes & 71 \\
\hline Never & 30 \\
\hline
\end{tabular}

that almost 20 respondents has the interest to follow the English training, it shows with the frequency of "always" is the biggest one than other is 94 , but also there are a few of them has no interest to follow that training.

\section{Motivation}

The data of motivation is taken from the motivation questionnaires of lecturer in State Polytechnic of Balikpapan to follow the English training that has been done before by the Language Centre. Those data are given to the twenty respondents, which has ten questions that related to their motivation to follow some English training.

From ten questions that has given, there are four questions that indicates that someone have no motivation at all to follow the English learning program, they are question number 2, 5, 8 and 10. After done hypothesis such questionnaires, it can be known that the average respondent are does not have motivation to learn English. It can be shown that many respondent choose the answer "doubtful" and "disagree" with type of question that quantify them whether they are didn't have motivation at all. It can be shown in the table below:

Table 2. Motivation frequency

\begin{tabular}{|c|c|c|c|}
\hline Variable & Agree & Doubtful & Disagree \\
\hline Motivated & 87 & 26 & 4 \\
\hline $\begin{array}{c}\text { Unmotivate } \\
\mathrm{d}\end{array}$ & 22 & 33 & 28 \\
\hline
\end{tabular}

The table above shows that the numbers of doubtful and disagree for unmotivated person are more than motivated. The respondents prefer to choose doubtful and disagree for the questions: [1] English is difficult to learn than what I expected before, and [2] English exercise is too difficult to understand. Therefor, it can be concluded that the respondent commonly have motivation to learn English but they have difficulties to understand the materials.

Moreover, from questionnaires can also found some suggestions to make routine training or activity for the lecturer in State Polytechnic of Balikpapan as an effort to increase their skill in mastering English and also TOEFL.

\section{Learning achievement}

The data of learning achievement is taken from the final score of lecturer in State Polytechnic of Balikpapan when they follow the TOEFL test in Language Centre. This data show that from 35 lecturers that follow the test indicates that $34 \%$ have score between $300-400,51 \%$ have score between $400-500$, and $14 \%$ have score 2500 , which can be shown in graph below:

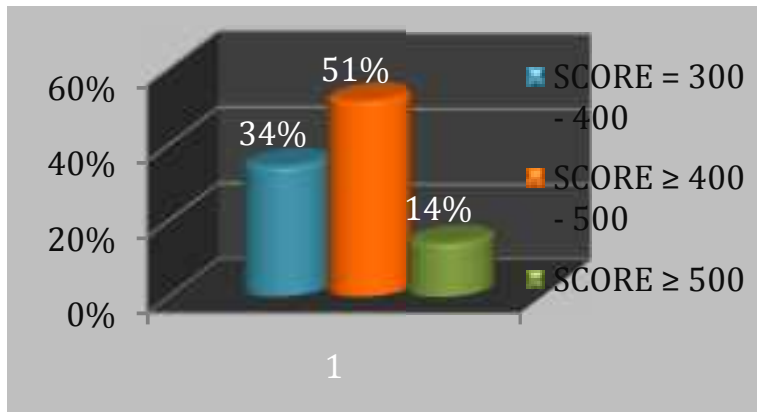

Picture 2. Graph of TOEFL score of lecturer in State Polytechnic of Balikpapan

From graph above, it can be concluded that the lecturer has lower skill in mastering English especially TOEFL, if it reviewed to interest and motivation, so that the result is relevant with the 
motivation analysis before, based on respondent, English is to difficult to learn and understand, therefor the learning result is lower too. If it categorized, the lecturer of State Polytechnic of Balikpapan is categorized as Well-motivated with Lowachievement Category, means that their lower comprehend ability and score are not caused of their lower interest, but it caused of their former skill is not good enough.

Their former skill that not good enough can be caused by the instructor and human factor which is called "limited memorize", both factors make them slowly to response the instructor stimulus.

\section{Conclusion}

- There is an interest of the lecturer in State Polytechnic of Balikpapan to follow the English training, it shows with the frequency of "always" in 94 frequency as the biggest one than other, but also there are a few of them has no interest to follow that training.

- There is a motivation of the lecturer in State Polytechnic of Balikpapan to learn English but they have difficulties to understand the materials.

- There is a well-motivated with Lowachievement Category for the lecturer of State Polytechnic of Balikpapan, means that their lower comprehend ability and score are not caused of their lower interest, but it caused of their former skill is not good enough.

\section{Suggestion}

Further research is needed to analyze the difficulties of learner in State Polytechnic of Balikpapan to learn English.

\section{References}

[1] Gunarwan, A. \& Hamid A. 2000. "Kedudukan dan Fungsi Bahasa Asing di Indonesia di dalam Era Globalisasi". Dalam Hasan Alwi dkk. Bahasa Indonesia dalam Era Globalisasi: Pemantapan Peran Bahas sebagai Saran Pembangunan Bangsa. Jakarta : Pusat Bahasa.

[2] Uno B. Hamzah, (2007). Teori motivasi Dan Pengukuran Analisis Di Bidang Pendidikan, cetakan kedua, Bumi Aksara, Jakarta.

[3] Dimyati dan Mudjiono, (2002). Belajar Dan Pembelajaran, Rineka Cipta. Jakarta.

[4] Arsyad, Azhar (2015) Dasar-dasar Penguasaan Bahasa Inggris melalui your basic vocabulary, Pustaka Pelajar. Yogyakarta.

[5] Sugiyono, (2008). Metode Penelitian, Pendekatan Kuantitatif, Kualitatif, dan $R \& D$. Alfabeta. Bandung. 